\title{
GROWTH, PHENOLOGY AND YIELD OF DROUGHT TOLERANT RAINFED RICE CULTIVARS TO STAGGERED TRANSPLANTING DATES UNDER CHANGING CLIMATIC SCENARIOS OF CENTERAL TERAI, NEPAL
}

\author{
D. B. Karki and L.P. Amgain \\ Institute of Agriculture and Animal Sciences, Tribhuvan University, Nepal
}

\begin{abstract}
A field experiment entitled "growth, phenology and yield of drought tolerant rainfed rice cultivars to staggered transplanting dates under changing climatic scenarios of centeral terai, Nepal" was conducted at farmer's field in Dhobadi VDC, Nawalparasi $\left(27^{\circ} 40^{\prime} \mathrm{N}, 84^{\circ} 05^{\prime} \mathrm{E}\right.$ and 235 masl) during June to November, 2012. The experimental soil was determined silt loam with slightly acidic reaction ( $\left.\mathrm{p}^{\mathrm{H}}-5.67\right)$. About $1960.40 \mathrm{~mm}$ of total rainfall was recorded at the experimental site during crop growing period which was $17.56 \%$ lower than average of the past 15 years $(2378 \mathrm{~mm})$. The experiment consisted sixteen treatment combinations arranged in splitplot design i.e. four transplanting dates in main-plot and four cultivars in sub-plot with three replications. The statistical result on grain yield revealed significant differences among dates of transplanting, however, varietal differences were found to be non-significant. The maximum $\left(2.46 \mathrm{tha}^{-1}\right)$ and minimum $\left(0.30 \mathrm{t} \mathrm{ha}^{-1}\right)$ grain yield were recorded for first transplanting date (July 15 ) and last transplanting date (August 14), respectively. Grain yield, number of grains panicle ${ }^{-1}$, filled grains panicle ${ }^{-1}$ and test weight recorded under July 15, July 25 and August 4 transplanted condition were statistically at par but was significantly superior over August 14 transplanting. The reduction in grain yield due to successive delay of 10 days from July 15 upto August 4 was to the extent of 12.6 and 28.6 percent, respectively. GDD received by rice cultivars was found significantly higher $\left(2830{ }^{\circ} \mathrm{C}\right)$ for July 15 transplanted rice at maturity stage, whereas, August 14 transplanted rice received significantly lower GDD $\left(2689^{\circ} \mathrm{C}\right)$ for maintaining maturity stage. Cultivar Sukkha Dhan-2 was found relatively more stable in using heat for all transplanting dates $(86.31 \%)$ followed by Sukkha Dhan-3 (86.66 \%), Sukkha Dhan-1 (88.31\%) and Radha-4 $(88.37 \%)$.
\end{abstract}

Key words: Changing climatic scenarios, Drought tolerant rainfed rice cultivars, Staggered transplanting date

\section{INTRODUCTION}

Rice (Oryza sativa L), the major staple food of more than half of the global population is also the major crop of Nepal, sharing about 20\% of AGDP, however, the lower yield of $3.31 \mathrm{t} \mathrm{ha}^{-1}$, (MoAD, 2011) is noticed as compared the highest yield of $12.0 \mathrm{t} \mathrm{ha}^{-1}$ in China (IRRI, 2010). The major reason of low yield is due to its cultivation in rainfed environment. Rainfed lowland rice is usually transplanted, that is grown in levelled and bunded fields that are shallowly flooded with rainwater. In Nepal, rice production area under irrigated and rainfed condition are 49.96 and 50.04\%, respectively (MoAD, 2011). The yield of rice under rainfed and irrigated conditions in Nepal are 2.5 and $3.4 \mathrm{tha}^{-1}$, respectively (MoAD, 2012). 
Climate change refers to the persistent change in the mean and variability of climatic parameters (temperature, rainfall, humidity and solar radiation) of a location due to change in composition of GHGs. Temperature of Nepal has increased by $0.06^{\circ} \mathrm{C}$ annually on an average. Rainfall has been increased by $13 \mathrm{~mm}$ and number of rainy days is being decreased by 0.8 days per year (Dahal, 2009). Air and water temperature influence the crop duration and yield performance of rice which is more pronounced in rainfed condition (Dingkuhn et al., 1995). Optimum temperature for the better growth and development of rice is $25-30^{\circ} \mathrm{C}$. Evenly distributed rain, even in low amount (1200-1500 $\mathrm{mm}$ ) is beneficial for rice production (De Datta, 1981) than unevenly distributed high amount of rainfall more that $1500 \mathrm{~mm}$ (Mitin, 2009). The onset, duration and cessation of monsoon rainfall are being irregular these days. This erratic rainfall pattern causes delay in rice transplanting resulting decline in crop growth period and ultimately yield due to water stress at various growth stages of the crop. Delay planting results in higher disease and insect incidence and possible cold damage during heading and grain filling period resulting low grain yield (Groth and Lee, 2003). Most of the rice varieties released till now in Nepal are susceptible to drought stress (Serraj et al., 2009). Heat use efficiency in terms of dry matter or yield is important aspect which has great practical applications (Amgain, 2011). The efficiency of conversion of heat into the dry matter depends upon the genetic factors, sowing time and crop type (Rao et al., 1999).

At farmer's level, adoptive mechanisms against climate change impact on agriculture would be using short duration drought tolerant cultivars and adjusting sowing/planting time of crop. Optimum planting time of the rice crop is important for two major reasons. Firstly, it ensures that vegetative growth occurs during a period of satisfactory temperatures and high levels of solar radiation. Secondly, it guarantees that grain filling occurs when milder autumn temperatures are more likely, hence good grain quality is achieved (Farrell et al., 2003). The present investigation was aimed therefore to view the impact of climate change on various rice cultivars and transplanting dates under rainfed condition.

\section{MATERIALS AND METHODS}

A field experiment was conducted at Dhobadi VDC, Nawalparasi $\left(27^{\circ} 40^{\prime} \mathrm{N}, 8^{\circ} 05^{\prime} \mathrm{E}\right.$ and 235 masl) during June to November, 2012 in a farmer's field under rainfed condition. There were sixteen treatments with 3 replications based on four transplanting dates at 10 days interval (July 15, July 25, August 4 and August 14) and four drought tolerant rice cultivars (Sukkha Dhan-1, Sukkha Dhan-2, Sukkha Dhan-3 and Radha-4) arranged in split-plot design i.e. transplanting dates in main-plot and cultivars in sub-plot. The rice cultivars received differential average temperature (Fig.1) during its growth stages. The total rainfall throughout the entire crop growing period (June to November) was observed $1960.40 \mathrm{~mm}$. The maximum mean temperature decreased from $38.28^{\circ} \mathrm{C}$ ( $2^{\text {nd }}$ week of June) to $26.63^{\circ} \mathrm{C}$ (last week of November); and minimum mean temperature reduced from $26.45^{\circ} \mathrm{C}\left(1^{\text {st }}\right.$ week of July) to $12.02^{\circ} \mathrm{C}$ (last week of November). The soil of experimental plot was silt loam with acidic reaction $\left(\mathrm{p}^{\mathrm{H}}-5.67\right)$. Soil organic matter $(1.58 \%)$, total nitrogen $(0.08 \%)$ and available $\mathrm{P}_{2} \mathrm{O}_{5}$ $\left(28.9 \mathrm{~kg} \mathrm{ha}^{-1}\right)$ were found low whereas available $\mathrm{K}_{2} \mathrm{O}\left(185.7 \mathrm{~kg} \mathrm{ha}^{-1}\right)$ was observed medium.

Nursery beds were raised separately for each variety and 22 days old seedlings were transplanted in all transplanting dates. The standard package of practice was followed to grow rice. 
Observations regarding yield attributing traits (effective tillers $\mathrm{m}^{-2}$, number of total grains panicle ${ }^{-1}$, filled grains panicle ${ }^{-1}$, thousand grains weight) were recorded. Average mean temperature received by the drought tolerant rice cultivars from sowing to harvesting under different transplanting dates have been depicted in figure 1. Agrometerological indices such as accumulated growing degree days (AGDD) and heat use efficiency (HUE) were calculated to predict the phenology and yield of rice (Rajput et al., 1987).

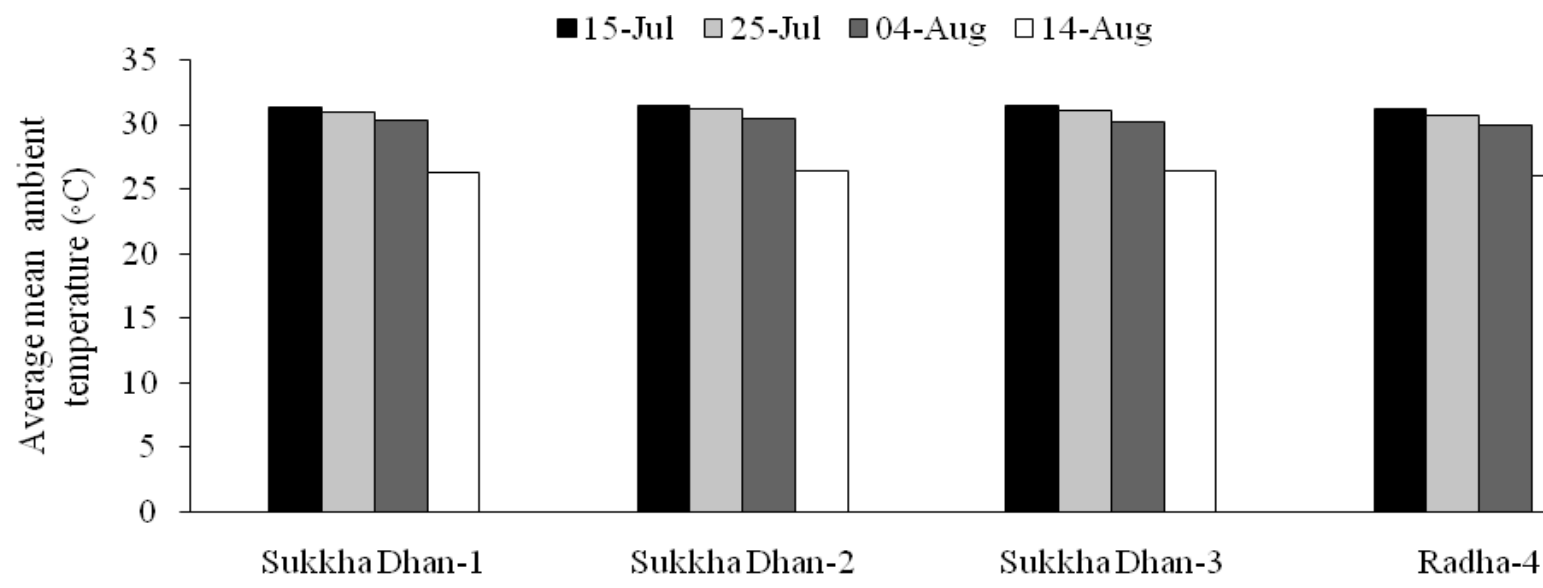

Rice Cultivars

Figure 1. Average mean ambient temperature received by different rice cultivars under different transplanting dates at Dhobadi, Nawalparasi, 2012

1. $\operatorname{AGDD}\left({ }^{\circ} \mathrm{C}\right.$ day $)=\sum_{i}^{n}==_{1}\left\{\frac{(T \max +T \min )}{2}-T b\right.$

Where, Tmax and Tmin are maximum and minimum temperatures of the day, respectively. And $\mathrm{Tb}$ is the base temperature for rice crop which is $10^{\circ} \mathrm{C}$ i.e below this temperature, there is no crop growth.

2. HUE $=\frac{\text { Grain yield }\left(\frac{\mathrm{kg}}{\mathrm{ha}}\right)}{\text { Accumulated heat units }{ }^{\circ} \mathrm{C}}$

\section{RESULTS AND DISCUSSION}

\section{Effect of transplanting dates and cultivars on agro-meteorological indices}

The effect of transplanting dates and cultivars on Growing degree days (GDD) at different phenological stages of drought tolerant rice was found significant (Table 1). GDD received by rice cultivars was found significantly higher $\left(2830^{\circ} \mathrm{C}\right)$ for July 15 transplanted rice at maturity stage, whereas, August 14 transplanted rice received significantly lower GDD $\left(2689{ }^{\circ} \mathrm{C}\right)$ for maintaining maturity stage. Paul and Sarker (2000) also reported that requirement of GDD decreased for different phenological stages with delay in sowing. 
Table 1. Growing degree days (GDD) at different phenological stages of different drought tolerant rice as affected by transplanting dates and cultivars at Dhobadhi, Nawalparasi, 2012

\begin{tabular}{lccccccc}
\hline & \multicolumn{7}{c}{ Growing degree days $\left({ }^{\circ} \mathrm{C}\right.$ day $)$} \\
\cline { 2 - 8 } Treatments & $\begin{array}{c}\text { Panicle } \\
\text { Initiation }\end{array}$ & Booting & Heading & Flowering & Milking & Hard dough & Maturity \\
\hline Transplanting dates & & & & & & & \\
July 15 & $1027^{\mathrm{a}}$ & $1671^{\mathrm{a}}$ & $1936^{\mathrm{b}}$ & $2032^{\mathrm{a}}$ & $2251^{\mathrm{a}}$ & $2568^{\mathrm{a}}$ & $2830^{\mathrm{a}}$ \\
July 25 & $1035^{\mathrm{a}}$ & $1712^{\mathrm{a}}$ & $1976^{\mathrm{a}}$ & $2039^{\mathrm{a}}$ & $2249^{\mathrm{a}}$ & $2590^{\mathrm{a}}$ & $2780^{\mathrm{b}}$ \\
August 4 & $1008^{\mathrm{b}}$ & $1662^{\mathrm{a}}$ & $1911^{\mathrm{b}}$ & $2013^{\mathrm{a}}$ & $2198^{\mathrm{b}}$ & $2559^{\mathrm{a}}$ & $2768^{\mathrm{b}}$ \\
August 14 & $941^{\mathrm{c}}$ & $1487^{\mathrm{b}}$ & $1834^{\mathrm{c}}$ & $1911^{\mathrm{b}}$ & $2098^{\mathrm{c}}$ & $2390^{\mathrm{b}}$ & $2689^{\mathrm{c}}$ \\
\hline SEM $( \pm)$ & 3.52 & 17.00 & 10.61 & 8.55 & 12.89 & 14.24 & 9.02 \\
LSD (p=0.05) & 12.21 & 3.53 & 36.74 & 10.62 & 44.61 & 49.28 & 31.24 \\
\hline Cultivars & & & & & & & \\
Sukkha Dhan-1 & $973^{\mathrm{c}}$ & $1586^{\mathrm{c}}$ & $1843^{\mathrm{c}}$ & $1926^{\mathrm{b}}$ & $2132^{\mathrm{b}}$ & $2488^{\mathrm{b}}$ & $2748^{\mathrm{b}}$ \\
Sukkha Dhan-2 & $972^{\mathrm{c}}$ & $1554^{\mathrm{d}}$ & $1835^{\mathrm{c}}$ & $1931^{\mathrm{b}}$ & $2134^{\mathrm{b}}$ & $2454^{\mathrm{b}}$ & $2703^{\mathrm{b}}$ \\
Sukkha Dhan-3 & $1008^{\mathrm{b}}$ & $1639^{\mathrm{b}}$ & $1887^{\mathrm{b}}$ & $1936^{\mathrm{b}}$ & $2161^{\mathrm{b}}$ & $2485^{\mathrm{b}}$ & $2734^{\mathrm{b}}$ \\
Radha-4 & $1057^{\mathrm{a}}$ & $1753^{\mathrm{a}}$ & $2093^{\mathrm{a}}$ & $2201^{\mathrm{a}}$ & $2367^{\mathrm{a}}$ & $2681^{\mathrm{a}}$ & $2881^{\mathrm{a}}$ \\
\hline SEM ( \pm ) & 3.10 & 8.80 & 6.30 & 12.46 & 10.05 & 13.15 & 17.05 \\
LSD (p=0.05) & 9.05 & 25.69 & 18.42 & 36.37 & 29.34 & 38.39 & 49.76 \\
\hline CV (\%) & 1.07 & 1.87 & 1.14 & 2.16 & 1.58 & 1.80 & 2.13 \\
\hline
\end{tabular}

Treatments mean followed by common letter (s) within column are not significantly different among each other based on DMRT at $5 \%$ level of significance.

\section{Effect of transplanting dates and cultivars on yield attributing traits}

Effective tillers $\mathrm{m}^{-2}$, total number of grains panicle ${ }^{-1}$, number of filled grains panicle ${ }^{-1}$ were influenced only due to cultivars (Table 2). Among the cultivars, Sukkha Dhan-2 showed comparatively higher tillers number $\mathrm{m}^{-2}$ (203.90), whereas comparatively lower effective number of tillers $\mathrm{m}^{-2}$ (187.40) was found in the Sukkha Dhan-3. Significant difference in effective tillers $\mathrm{m}^{-2}$ among the cultivars might be due to their genotypic characteristic. The difference in tiller production among cultivars may be attributed to varietal characters (Chandrashekhar et al., 2001). The average number of grains panicle ${ }^{-1}$ was observed 132.59. Rice transplanted on July 25 showed maxium total grains panicle ${ }^{-1}$ (135.50) whereas minimum number of grains panicle ${ }^{-1}$ (124.50) was recorded for the rice transplanted on August 14 . Fewer number of grains panicle ${ }^{-1}$ of transplanted rice on August 14 might be due to shortened growth period of the plant which reduced the leaf area and leaf duration, ultimately reducing assimilate development. According to Biswas and Salokhe (2001), grains panicle ${ }^{-1}$ showed better response with early sowing. In case of cultivar, comparatively higher total grains panicle ${ }^{-1}$ (140.40) was recorded for Sukkha Dhan-1 followed by Sukkha Dhan-2, whereas Sukkha Dhan-3 showed comparatively few total grains panicle ${ }^{-1}(125.20)$.

The maximum number of filled grains panicle ${ }^{-1}$ (110.6) was found on July 15 transplanted rice followed by that transplanted on July 25 and August 4. Whereas rice transplanted on August 14 gave the least number of filled grains panicle ${ }^{-1}$ (91.63). This might be because of poor crop growth and development due to soil moisture stress at critical growth stages as a result of less rainfall during the growing period. The result is in agreement with the findings of Shah and Bhurer (2005) who reported higher number of grains panicle ${ }^{-1}$ in the earlier transplanted rice and declined gradually in the successive transplanting dates. Among cultivars, Sukkha Dhan-2 showed maximum number 
of filled grains panicle ${ }^{-1}$ (114.30), whereas Sukkha Dhan-3 gave minimum number of filled grains panicle $^{-1}(94.15)$.

Table 2. Yield attributing traits of drought tolerant rice as influenced by transplanting dates and cultivars at Dhobadi, Nawalparasi, 2012

\begin{tabular}{|c|c|c|c|c|c|}
\hline \multirow[b]{2}{*}{ Treatments } & \multicolumn{5}{|c|}{ Yield attributes } \\
\hline & $\begin{array}{l}\text { Effective } \\
\text { tillers } \mathrm{m}^{-2}\end{array}$ & $\begin{array}{c}\text { Total } \\
\text { grains panicle }^{-1}\end{array}$ & $\begin{array}{c}\text { Filled } \\
\text { grains panicle }^{-1}\end{array}$ & $\begin{array}{c}\text { Sterility } \\
\text { percentage }\end{array}$ & $\begin{array}{c}\text { Test weight } \\
\text { (g) }\end{array}$ \\
\hline \multicolumn{6}{|c|}{ Transplanting dates } \\
\hline July 15 & 183.66 & $134.90^{\mathrm{a}}$ & $110.60^{\mathrm{a}}$ & $18.29^{b}$ & $23.84^{\mathrm{a}}$ \\
\hline July 25 & 207.47 & $135.50^{\mathrm{a}}$ & $108.70^{\mathrm{a}}$ & $19.97^{\mathrm{b}}$ & $23.81^{\mathrm{a}}$ \\
\hline August 4 & 205.06 & $135.40^{\mathrm{a}}$ & $107.20^{\mathrm{a}}$ & $21.03^{\mathrm{b}}$ & $22.35^{\mathrm{ab}}$ \\
\hline August 14 & 177.91 & $124.50^{\mathrm{b}}$ & $91.63^{\mathrm{b}}$ & $26.70^{\mathrm{a}}$ & $21.02^{\mathrm{b}}$ \\
\hline SEM $( \pm)$ & 12.67 & 1.40 & 1.83 & 0.77 & 0.53 \\
\hline $\operatorname{LSD}(p=0.05)$ & N.S & 4.86 & 6.34 & 2.66 & 1.84 \\
\hline \multicolumn{6}{|l|}{ Cultivars } \\
\hline Sukkha Dhan-1 & $192.80^{\mathrm{ab}}$ & $140.40^{\mathrm{a}}$ & $113.60^{\mathrm{a}}$ & $19.30^{\mathrm{b}}$ & 23.09 \\
\hline Sukkha Dhan-2 & $203.90^{\mathrm{a}}$ & $139.10^{\mathrm{a}}$ & $114.30^{\mathrm{a}}$ & $17.90^{\mathrm{b}}$ & 22.97 \\
\hline Sukkha Dhan-3 & $187.40^{\mathrm{b}}$ & $125.20^{\mathrm{b}}$ & $94.15^{\mathrm{b}}$ & $24.99^{\mathrm{a}}$ & 22.23 \\
\hline Radha-4 & $190.10^{\mathrm{b}}$ & $125.70^{\mathrm{b}}$ & $96.02^{\mathrm{b}}$ & $23.80^{\mathrm{a}}$ & 22.73 \\
\hline SEM $( \pm)$ & 4.08 & 2.64 & 2.74 & 0.60 & 0.55 \\
\hline $\operatorname{LSD}(p=0.05)$ & 11.91 & 7.70 & 8.00 & 1.78 & N.S \\
\hline CV (\%) & 7.30 & 6.89 & 9.09 & 9.80 & 8.32 \\
\hline
\end{tabular}

N.S = Non Significant; Treatments mean followed by common letter (s) within column are not significantly different among each other based on DMRT at $5 \%$ level of significance.

Both the transplanting dates and cultivars had significant influence on the grain sterility percentage; however, only the the transplanting dates influenced the thousand grains weight significantly (Table 2). rice transplanted on July 15 showed minimum sterility percentage (18.29) while it was maximum for that transplanted on August 14 (26.70). Lower sterility percentage of rice transplanted on July 15 was due to higher number of filled grains panicle ${ }^{-1}$. The exposure of critical reproductive phases of rice plant to cold temperature and infestation of rice Gundhi bugs during milking stage aggravate to increase grain sterility percentage for August 14 transplanted rice. Among cultivars, minimum (17.90) and maximum (24.99) sterility percentage was seen in Sukkha Dhan-2 and Sukkha Dhan-3, respectively. Comparatively higher test weight (23.84 g) was recorded in rice transplanted on July 15 followed by that transplanted on July 25 and August 4 whereas rice transplanted on August 14 had minimum test weight (21.02 g). Higher test weight in earlier transplanted rice might be due to more photosynthate accumulation in grains due conducive environmental condition through out the growing period.

\section{Effect of transplanting dates and cultivars on yield}

Effect of transplanting date on grain and straw yield were significant (Table 3). The maximum $\left(2.46 \mathrm{t} \mathrm{ha}^{-1}\right)$ and minimum $\left(0.30 \mathrm{t} \mathrm{ha}^{-1}\right)$ grain yield were obtained from rice transplanted on July 15 and August 14, respectively. Grain yield obtained under that transplanted on July 15, July 25 and August 4 being statistically at par, was significantly superior over the transplanted on August 14 . The reduction in grain yield due to successive delay in transplanteing of 10 days from July 15 was to the extent of $12.6 \%$ and $28.6 \%$ respectively. However rice transplanted on August 14 resulted $87.89 \%$ decrease in grain yield as compared to that transplanted on July 15 and the reduction was 
significant (Figure 2). The result found by Singh et al. (1997) is in line with these findings, who reported that yields were higher with early seeding than with late seeding. The effect of cultivar on grain yield was non-significant (Table 3) however, Sukkha Dhan-2 yielded the highest (1.94 t ha-1) and Sukkha Dhan-3 yielded the lowest $\left(1.48 \mathrm{t} \mathrm{ha}^{-1}\right)$. Straw yield was recorded maximum $\left(7.21 \mathrm{t} \mathrm{ha}^{-1}\right)$ in rice transplanted on July 25 and minimum (4.39 $\left.\mathrm{t} \mathrm{ha}^{-1}\right)$ in that transplanted on August 14. Among cultivars, higher straw yield (7.05 $\left.\mathrm{tha}^{-1}\right)$ was seen in Radha-4 and less straw yield $\left(5.52 \mathrm{t} \mathrm{ha}^{-1}\right)$ was seen in Sukkha Dhan-3.

Table 3. Effect of transplanting dates and cultivars on grain yield, straw yield and harvest index of drought tolerant rice at Dhobadi, Nawalparasi, 2012

\begin{tabular}{lccc}
\hline Treatments & Grain yield $\left(\mathrm{t} \mathrm{ha}^{-1}\right)$ & Straw yield $\left(\mathrm{t} \mathrm{h}^{-1}\right)$ & Harvest Index \\
\hline Transplanting Dates & & & \\
July 15 & $2.46^{\mathrm{a}}$ & 6.65 & 0.26 \\
July 25 & $2.15^{\mathrm{a}}$ & 7.21 & 0.22 \\
August 4 & $1.76^{\mathrm{a}}$ & 6.54 & 0.21 \\
August 14 & $0.30^{\mathrm{b}}$ & 4.39 & 0.07 \\
\hline SEM $( \pm)$ & 0.29 & 0.98 & 0.02 \\
LSD (p=0.05) & 1.015 & $\mathrm{~N} . \mathrm{S}$ & $\mathrm{N} . \mathrm{S}$ \\
\hline Cultivars & & & \\
Sukkha Dhan-1 & 1.67 & 6.29 & 0.20 \\
Sukkha Dhan-2 & 1.94 & 5.93 & 0.22 \\
Sukkha Dhan-3 & 1.48 & 5.52 & 0.19 \\
Radha -4 & 1.58 & 7.05 & 0.15 \\
\hline SEM $( \pm)$ & 0.24 & 0.52 & 0.02 \\
LSD (p=0.05) & N.S & N.S & N.S \\
\hline CV $(\%)$ & 49.63 & 28.87 & 31.65 \\
\hline N.S $=$ Non Signifar
\end{tabular}

N.S = Non Significant; Treatments mean followed by common letter (s) within column are not significantly different among each other based on DMRT at 5\% level of significance.

The effect of transplanting dates and cultivars were found non-significant on harvest index (Table 3). However rice transplanted on July 15 gave maximum HI (0.26) and that with the minimum $\mathrm{HI}$ of rice transplanted on August 14 (0.07). Among the cultivars, Sukkha Dhan-2 gave comparatively higher HI (0.22).

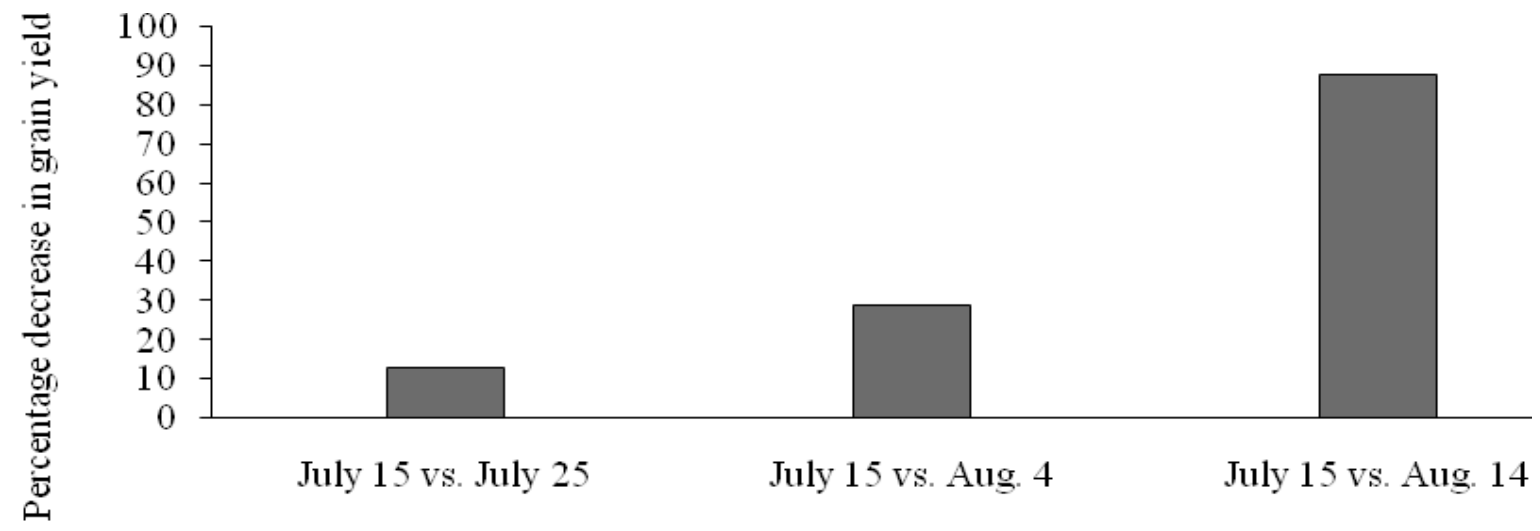

Shifting of transplanting dates 
Figure 2. Percentage decrease in grain yield due to delay in transplanting of drought tolerant rice cultivars at Dhobadi, Nawalparasi, 2012

Heat Use Efficiency (HUE)

Table 4 shows that most of the cultivars were more efficient in using heat at earlier growing condition (normal condition) than the late growing condition.

Table 4. Heat use efficiency (HUE) of different rice cultivars as affected by transplanting dates and cultivars

\begin{tabular}{|l|c|c|c|c|c|}
\hline \multirow{2}{*}{ cultivars } & \multicolumn{4}{|c|}{ Heat use efficiency (HUE) } & $\begin{array}{c}\text { Reduction \% } \\
\text { from July 15 } \\
\text { to August 14 }\end{array}$ \\
\cline { 2 - 5 } & July 15 & July 25 & August 4 & August 14 & 88.31 \\
\hline Sukkha Dhan-1 & 0.77 & 0.79 & 0.75 & 0.09 & 86.31 \\
\hline Sukkha Dhan-2 & 0.95 & 1.13 & 0.65 & 0.13 & 86.66 \\
\hline Sukkha Dhan-3 & 0.9 & 0.66 & 0.46 & 0.12 & 88.37 \\
\hline Radha-4 & 0.86 & 0.53 & 0.68 & 0.10 & \\
\hline
\end{tabular}

Sukkha Dhan-2 transplanted on July 25 recorded the highest heat use efficiency (1.13) and Radha- 4 cultivar transplanted on August 14 showed the lowest heat use efficiency ( 0.10 in interaction result of transplanting dates and cultivars. For almost all cultivars, heat use efficiency recorded was found to be decreased gradually as the transplanting date was delayed. The magnitudes of decrease were found to be less when going from July 15 to July 25 and July 25 to August 4 . Whereas the reductions in heat use efficiency for all cultivars when going from July 15 to August 15 were recorded more than $85 \%$. (Table 4). Cultivar Sukkha Dhan-2 was found relatively more stable in using heat for all transplanting dates (86.31\%) followed by Sukkha Dhan-3 (86.66 \%), Sukkha Dhan-1 (88.31\%) and Radha-4 (88.37\%).

\section{CONCLUSION}

In context of changing climatic scenario under rainfed condition in central terai of Nepal, the drought tolerant rice cultivars can be transplanted within July to escape the effect of late season drought on critical growth stages. However, at least two years of multi-location research is needed to validate this research further.

\section{ACKNOWLEDGEMENT}

The authors would like to express their sincere thanks to Caritas Nepal for providing research thesis grant to accomplish this study.

\section{REFERENCES}

Amgain, L.P. 2011. Agro-meterological indices in relation to phenology of promising rice cultivars in Chitwan, Nepal. Nepal Agriculture Research Journal. 11: 52- 59.

Biswas, P.K. and V.M. Salokhe. 2001. Effects of planting date, intensity of tiller separation and plant density on the yield of transplanted rice. J. Agric. Sci. 137(3): 279-287.

Chandrasekhar, J., G. Rana Rao, B. Ravindranath and K.B. Reddy. 2001. Physiological analysis of growth and productivity in hybrid rice (Oryza sativa). Indian J. Plant Physio. 6(2): 142-146.

Dahal, N.M. 2009. Emerging trend of change in rainfall pattern and its impact on traditional farming system: a case study of paddy cultivation in Kirtipur municipality. Thesis. Pokhara University. 
De Datta, S.K. 1981. Principles and practices of rice production. New York, John Willey and Sons. $618 \mathrm{p}$.

Dingkuhn, M., A. Sow, A. Samb, S. Diack and F. Asch. 1995. Climatic determination of irrigated rice performance in the Sahel. In photothermal and micro climatic responses of flowering. Agricultural Systems. 48: 385-410.

Farrell, T.C., K. Fox, R. L.Williams, S. Fukai and L.G. Lewin. 2003. Avoiding low temperature damage in Australia's rice industry with photoperiod sensitive cultivars. Proceedings of the 11th Australian Agronomy Conference. Geelong, 2-6 February 2002. Australia , Deakin University.35p.

Groth, D.E. and F.N. Lee. 2003. Rice diseases. In :C.W. Smith and R.H. Dilday (Eds.). Rice: Origin, history, technology, and production. John Wiley and sons, Hoboken, New Jersey, pp. 413436.

IRRI, 2010. Scuba Rice: Breeding Flood Tolerance into Asia's Local Mega Rice Cultivars. International Rice Research Institute, .Los Banos Philippines: Available on www.eiard.org/ media/uploads/documents/case_studies/dfid_impact_case_study_sub1_rice [Retrieve on 10th September, 2012].

Mitin, A. 2009. Documentation of selected adaptation strategies to climate change in rice. East Asia rice working group. Philippines: Action for economic reform.

MoAD. 2012. Statistical Information on Nepalese Agriculture. Government of Nepal. Ministry of Agriculture and Cooperatives. Agri. Business Promotion and Statistics Division. Singh Durbar, Kathmandu, Nepal

MoAD. 2011. Statistical Information on Nepalese Agriculture. Government of Nepal. Ministry of Agriculture and Cooperatives. Agri. Business Promotion and Statistics Division. Singh Durbar, Kathmandu, Nepal.

Paul, N.K. and D.K. Sarker. 2000. Accumulated heat units and phenology relationships in wheat as influenced by sowing dates. Bangladesh J. Bot. 29(1):49- 54.

Rajput, R.P., M.R. Deshmukh and V. K. Paradkar 1987. Accumulated heat unit and phenology relationships in wheat (Triticum aestivum $\mathrm{L}$ ) as influenced by planting dates under late sown conditions. J. Agron. Crop Sci. 159: 345- 348.

Rao, V.U. M., D. Singh and R Singh. 1999. Heat use efficiency of winter crops in Haryana. Journal of Agro-meterology 1(2): 143-148.

Serraj R, Kumar A, McNally KL, Slamet-Loedin I, Bruskiewich R, Mauleon R, Cairns J, Hijmans R J. 2009. Improvement of drought resistance in rice. Adv. Agron. 103:41-99.

Shah, L.M. and K.P. Bhurer. 2005. Response of wet seeded rice cultivars to sowing dates. Nepal Agric.Res. J. 6: 35-38.

Singh, K.M., S.K. Pal, U.N. Verma, R. Thakur and M.K. Singh. 1997. Effect of time and methods of planting on performance of rice (Oryza sativa L.) cultivars under medium lands of Bihar Plateau. Indian J. Agron. 42: 443-445. 